\title{
PENGKEMASAN PAKET WISATA TRACKING DENGAN KONSEP TRI HITA KARANA DI DESA MUNDUK-BULELENG
}

\author{
Nyoman Surya Maha Putra \\ I Wayan Suardana \\ I Putu Sudana \\ Email: nyomansuryamahaputra@yahoo.com \\ PS. S1 Industri Perjalanan Wisata \\ Fakultas Pariwisata UNUD
}

\begin{abstract}
Munduk village is located in the district of Banjar, Buleleng regency, which has a variety of attractions that can be developed. The purpose of this study was to determine the potential of tourism and packaging of tracking package tour with the concept of Tri Hita Karana in Munduk Village, Buleleng. The informants technique used in this research is purposive sampling. The informants in this research consisted of The chief of Munduk village, leaders community, and local guides. The analysis data technique used is descriptive qualitative. The results of this research indicated that Munduk has tourism potential in terms of natural landscapes, arts, local community trust, habits of the population, and historic buildings. Based on this potential, Tracking activities in Munduk village will packed into a tour packages by applying the concept of Tri Hita Karana. The tracking tour packages is divided into two options, namely Munduk Waterfall Tracking and Munduk Rice Field Tracking.
\end{abstract}

Keywords: Potential, Tracking, Tour Package.

\section{PENDAHULUAN}

Bali merupakan destinasi wisata terbaik di Indonesia, dimana memiliki berbagai potensi wisata berupa keindahan alam, seni budaya, dan adat istiadatnya di setiap daerah. Kabupaten Buleleng adalah salah satu contoh wilayah Bali yang memiliki daerah-daerah dengan berbagai potensi wisata yang dapat dikembangkan, seperti Desa Munduk yang terletak di Kecamatan Banjar. Lokasi desa tersebut berada di kawasan yang strategis, dimana akses atau jalur untuk menuju ke Desa Munduk juga merupakan salah satu jalur alternatif bagi wisatawan yang ingin mengunjungi obyek wisata yang ada di kawasan Bedugul dengan obyek wisata Pantai Lovina.

Konsep Tri Hita Karana merupakan landasan dalam menjalani kehidupan seharihari masyarakat lokal di Desa Munduk yang terdiri dari hubungan manusia dengan Tuhan, hubungan manusia dengan manusia, dan hubungan manusia dengan alam. Namun seiring berkembangnya pariwisata di Desa Munduk membuat kesadaran masyarakat sedikit berkurang, khususnya dalam hal menjaga dan merawat alam. Tentunya hal tersebut merupakan ancaman bagi perkembangan pariwisata di Desa Munduk.

Wisata tracking merupakan solusi tepat dalam memanfaatkan potensi alam yang belum diketahui luas oleh banyak wisatawan yang berkunjung ke Desa Munduk, dimana kegiatan wisata tracking nantinya dapat menarik minat wisatawan apabila kegiatan tersebut dipadukan dengan konsep Tri Hita Karana yang terdiri dari hubungan manusia dengan Tuhan, manusia dengan manusia, dan manusia dengan alam. Dampak wisata tracking tersebut juga tentunya memberikan pengaruh positif terhadap perekonomian masyarakat dan lingkungan. Adapun tujuan yang dimaksud yaitu untuk mengetahui potensi wisata dan pengkemasan paket wisata tracking dengan konsep Tri Hita Karana di Desa Munduk. 


\section{METODE}

Lokasi yang digunakan terletak di Desa Munduk, Kecamatan Banjar, Kabupaten Buleleng, Provinsi Bali. Adapun definisi operasional variabel yang terdiri atas potensi, pengkemasan paket wisata tracking, dan konsep Tri Hita Karana. Variabel potensi ditinjau berdasarkan teori menurut Yoeti (2002:5) bahwa segala sesuatu yang dapat menarik wisatawan untuk berkunjung pada suatu daerah tujuan wisata, yang dikarenakan dengan adanya natural attraction, cultural attraction, social attractions, dan built attraction. Variabel pengkemasan paket wisata tracking juga ditinjau berdasarkan teori menurut Suyitno (2001:23) bahwa dalam mengkemas sebuah paket wisata, tentunya dibutuhkan perencanaan yang baik dan matang. Perencanaan merupakan pemikiran terhadap kegiatan di masa mendatang yang didasarkan pada pertimbangan-pertimbangan berupa nama tur, lama penyelenggaraan, waktu di perjalanan, waktu untuk kegiatan di objek, waktu untuk istirahat, dan harga wisata. Sedangkan variabel konsep Tri Hita Karana ditinjau berdasarkan teori dalam buku Tri Hita Karana Tourism Awards \& Accreditation (2012:72) bahwa Tri Hita Karana merupakan sebuah konsep yang didasarkan atas keharmonisan hidup yang terdiri dari tiga unsur yang saling berkaitan yaitu parahyangan (hubungan manusia dengan Tuhan), pawongan (hubungan manusia dengan manusia), dan palemahan (hubungan manusia dengan alam).

Teknik pengumpulan data yang digunakan terdiri dari observasi dan wawancara mendalam. Penentuan informan dilakukan dengan teknik purposive sampling, yaitu teknik penentuan informan dengan berdasarkan pertimbangan subjektif peneliti (Utama dan Eka, 2012). Teknik analisis data yang digunakan adalah deskriptif kualitatif. Deskriptif kualitatif menurut (Sugiyono, 2012) merupakan metode yang digunakan untuk membedah suatu fenomena di lapangan. Data kualitatif dapat berguna untuk memaparkan situasi yang digambarkan dengan kata-kata atau kalimat yang didasarkan pada hasil observasi di Desa Munduk berupa gambaran umum Desa Munduk, sejarah perkembangan pariwisata, berbagai potensi wisata yang terdapat di Desa Munduk, dan kegiatankegiatan yang dapat dikemas dalam paket wisata tracking.
HASIL

Pada tahun 1906, Belanda telah menetapkan Desa Munduk menjadi tempat peristirahatan bagi orang-orang Belanda yang berkunjung ke Bali. Desa Munduk terletak pada ketinggian 900-1000 meter diatas permukaan laut. Desa Munduk terdiri dari empat dusun, yaitu Dusun Tamlingan, Beji, Taman, dan Bulakan dengan jumlah penduduk sekitar 5.800 jiwa. Desa Munduk memiliki luas wilayah sekitar 2.170 hektar, dimana sebagian besar lahan terdiri dari hutan, lahan pertanian, dan lahan perkebunan.

Potensi wisata yang dimiliki Desa Munduk meliputi air terjun Melanting dan air terjun Munduk atau lebih dikenal dengan Red Coral Waterfall. Kedua air terjun ini sangat menarik bagi wisatawan asing dikarenakan memiliki ukuran yang tinggi sekitar 80 meter dan memiliki massa air cukup besar. Area persawahan, hutan Munduk, perkebunanan cengkeh, dan perkebunan kopi juga merupakan berbagai potensi wisata yang tentunya dapat menarik minat wisatawan serta dapat memberi pengetahuan bagi wisatawan, dimana dari hutan tersebut gamelan tradisional rindik berasal.

Potensi wisata lainnya yaitu pasar tradisional, selain menjadi pusat perekonomian masyarakat, pasar tersebut juga merupakan daya tarik bagi wisatawan, dikarenakan wisatawan dapat melihat langsung kehidupan perekonomian masyarakat yang masih tergolong tradisional, seperti masih adanya sistem tukar barang (barter). Desa Munduk merupakan desa yang sebagian besar wilayahnya terdiri dari area perkebunan dan persawahan. Pura Kopi atau dikenal dengan Pura Subak Abian diperuntukkan bagi masyarakat lokal yang berprofesi sebagai petani di sektor perkebunan (cengkeh dan kopi), sedangkan Pura yang diperuntukkan bagi para petani di sektor persawahan yaitu Pura Bedugul atau dikenal dengan Pura Subak. Kedua Pura ini merupakan bangunan warisan leluhur yang sudah lama berdiri dan disakralkan oleh masyarakat setempat, sehingga menjadi salah satu potensi wisata di Desa Munduk.

Berdasarkan potensi tersebut, paket wisata tracking di Desa Munduk dapat dibagi menjadi dua jenis, serta dapat dilihat pendistribusian waktu untuk masing-masing 
paket wisata tracking pada Tabel 1 sebagai berikut.

Tabel 1. Jenis dan Pendistribusian Waktu Paket Wisata Tracking di Desa Munduk-Buleleng

\begin{tabular}{|c|c|c|c|}
\hline Uraian & Perjalanan & $\begin{array}{c}\text { Aktivitas } \\
\text { Tur }\end{array}$ & Istirahat \\
\hline \multicolumn{4}{|l|}{$\begin{array}{l}\text { Paket Munduk Waterfall } \\
\text { Tracking: }\end{array}$} \\
\hline Hotel - Pesanggrahan & $30^{\prime}$ & & \\
\hline $\begin{array}{l}\text { Pesanggrahan } \\
\text { Pesanggrahan - Hutan }\end{array}$ & & $30^{\prime}$ & $40^{\prime}$ \\
\hline Munduk & & $10^{\prime}$ & \\
\hline Hutan Munduk - Melanting & & & \\
\hline Waterfall & & $35^{\prime}$ & \\
\hline $\begin{array}{l}\text { Melanting Waterfall } \\
\text { Melanting Waterfall - }\end{array}$ & & & $15^{\prime}$ \\
\hline Perkebunan Cengkeh & & $35^{\prime}$ & \\
\hline $\begin{array}{l}\text { Perkebunan Cengkeh - } \\
\text { Coffee Break }\end{array}$ & & $15^{\prime}$ & \\
\hline Coffee Break & & & $15^{\prime}$ \\
\hline Coffee Break - Perkebunan & & & \\
\hline Kopi & & $5^{\prime}$ & \\
\hline Perkebunan Kopi - Toko & & & \\
\hline Handy Craft & & $15^{\prime}$ & \\
\hline Toko Handy Craft & & & $5^{\prime}$ \\
\hline Toko Handy Craft - Munduk & & & \\
\hline Waterfall & & $15^{\prime}$ & \\
\hline Munduk Waterfall & & & $15^{\prime}$ \\
\hline Munduk Waterfall - Cooking & & & \\
\hline Class & & $20^{\prime}$ & \\
\hline Cooking Class & & $70^{\prime}$ & \\
\hline Cooking Class - Pura Kopi & & $5^{\prime}$ & \\
\hline Pura Kopi & & & $15^{\prime}$ \\
\hline Pura Kopi - Hotel & $30^{\prime}$ & & \\
\hline Total & $60^{\prime}$ & $255^{\prime}$ & $105^{\prime}$ \\
\hline $\begin{array}{l}\text { Paket Munduk Rice Field } \\
\text { Tracking: }\end{array}$ & & & \\
\hline Hotel - Pesanggrahan & $30^{\prime}$ & & \\
\hline Pesanggrahan & & $30^{\prime}$ & $40^{\prime}$ \\
\hline Pesanggrahan - Pasar & & & \\
\hline Tradisional & & $10^{\prime}$ & \\
\hline Pasar Tradisional & & & $15^{\prime}$ \\
\hline Pasar Tradisional - & & & \\
\hline Perkebunan Cengkeh & & $20^{\prime}$ & \\
\hline Perkebunan Cengkeh - Area & & & \\
\hline Persawahan & & $35^{\prime}$ & \\
\hline Area Persawahan - & & & \\
\hline Perkebunan Kopi & & $20^{\prime}$ & \\
\hline Perkebunan Kopi - Hutan & & & \\
\hline Bambu & & $15^{\prime}$ & \\
\hline Hutan Bambu - Rest Area & & $10^{\prime}$ & \\
\hline Rest Area & & & $15^{\prime}$ \\
\hline Rest Area - Pura Bedugul & & $10^{\prime}$ & \\
\hline Pura Bedugul & & & $15^{\prime}$ \\
\hline Pura Bedugul - Cooking & & & \\
\hline Class & & $60^{\prime}$ & \\
\hline Cooking Class & & $75^{\prime}$ & \\
\hline Cooking Class - Hotel & $30^{\prime}$ & & \\
\hline Total & $60^{\prime}$ & $285^{\prime}$ & $85^{\prime}$ \\
\hline
\end{tabular}

Sumber: Hasil, 2016

Pada Tabel 1 tersebut, pendistribusian waktu pada paket wisata tracking di Desa
Munduk yaitu berdasarkan DOT After Adjusment (pendistribusian waktu setelah penyesuaian). Kedua paket wisata tracking memiliki jumlah waktu yang berbeda, jumlah waktu untuk menikmati paket Munduk Waterfall Tracking yaitu 420 menit, sedangkan jumlah waktu untuk menikmati paket Munduk Rice Field Tracking yaitu 430 menit, maka paket wisata tracking di Desa Munduk merupakan jenis paket wisata full day tour.

Implementasi konsep Tri Hita Karana dalam paket wisata tracking di Desa Munduk terdiri atas parahyangan (hubungan manusia dengan Tuhan) yaitu adanya kegiatan meditasi, mengunjungi dan mendapatkan penjelasan tentang tempat suci (Pura), pawongan (hubungan manusia dengan manusia) yaitu adanya kesempatan bagi wisatawan untuk berinteraksi dengan masyarakat lokal, serta adanya penjelasan tentang kegiatan dan organisasi masyarakat lokal, sedangkan palemahan (hubungan manusia dengan alam) yaitu adanya penjelasan tentang batas-batas alam dan komitmen untuk menjaga kebersihan serta tidak merusak tumbuh-tumbuhan demi pelestarian lingkungan di Desa Munduk.

\section{PEMBAHASAN}

Pengkemasan paket wisata tracking dalam hal ini adalah kumpulan kegiatan yang direncanakan, serta disusun dengan baik kedalam sebuah paket wisata berupa aktivitas petualangan yang dipadukan dengan kegiatan berlandaskan konsep Tri Hita Karana. Aktivitas wisata tracking ini tentu tidak hanya kegiatan perjalanan di alam pedesaan, namun terdapat kegiatan meditasi dan cooking class sebagai bentuk implementasi konsep Tri Hita Karana kedalam paket wisata tracking. Paket wisata ini akan disajikan dalam bentuk uraian, dengan starting point dan finishing point yaitu hotel yang terletak di kawasan objek wisata Lovina dengan menggunakan rata-rata kecepatan kendaraan $60 \mathrm{~km} / \mathrm{jam}$.

Durasi dalam menikmati objek pada setiap paket wisata tracking di Desa Munduk berbeda, dikarenakan jarak rute perjalanan dan objek kedua paket yang tidak sama, hal lainnya juga tergantung dari kemampuan atau faktor fisik wisatawan yang berbeda untuk melakukan wisata tracking. Perencanaan harga paket wisata tracking di Desa Munduk juga 
ditentukan berdasarkan CAT (Confidential Agent Tarif), dihitung dari perencanaan biaya secara kolektif. Pengkemasan paket wisata tracking di desa Munduk terdiri dari dua paket wisata yaitu Munduk Waterfall Tracking dan Munduk Rice Field Tracking, adapun penjelasan paket tersebut adalah sebagai berikut.

\section{Paket Wisata Munduk Waterfall Tracking}

Keberangkatan dimulai dari hotel yang terletak di kawasan Lovina, Kecamatan Buleleng pada pukul 07.00 WITA menuju Pesanggrahan di Desa Munduk. Setelah tiba di Pesanggrahan, wisatawan langsung menikmati sarapan pagi dengan menu yang berasal dari produk lokal. Wisatawan kemudian diarahkan menuju tempat meditasi. Kegiatan meditasi merupakan jalan untuk meraih ketenangan batin dan mendekatkan diri dengan Sang Pencipta (parahyangan atau hubungan manusia dengan Tuhan), kegiatan tersebut berlangsung selama 30 menit. Wisatawan yang sudah selesai bermeditasi akan diberikan waktu 10 menit untuk mempersiapkan perlengkapan dan mendapat penjelasan singkat tentang komitmen untuk tidak membuang sampah di setiap objek yang dikunjungi dan tidak merusak tumbuh-tumbuhan demi pelestarian lingkungan di Desa Munduk (palemahan atau hubungan manusia dengan alam). Perjalanan awal dimulai dari memasuki kawasan hutan di Desa Munduk, dimana dari hutan tersebutlah wisatawan dapat melihat pohon bambu yang digunakan masyarakat lokal untuk membuat alat musik tradisional rindik. Selanjutnya wisatawan dapat melihat salah satu keindahan alam Desa Munduk yaitu Air Terjun Melanting yang dikenal dengan air deras dan hawanya yang sejuk. Setelah menikmati pemandangan dan bersantai di air terjun, wisatawan melanjutkan perjalanan dengan menaiki 400 anak tangga. Selanjutnya wisatawan akan memasuki area perkebunan cengkeh. Pada saat memasuki perkebunan cengkeh, wisatawan dapat melihat dan mendapatkan penjelasan tentang organisasi masyarakat Dharma Sawitra (kumpulan masyarakat lokal Desa Munduk yang berprofesi sebagai petani perkebunan cengkeh dan kopi) sebelum menuju rest area yang sudah disediakan untuk menikmati coffee break serta dapat berinteraksi dengan masyarakat lokal. Perjalanan dimulai kembali dengan mengunjungi perkebunan kopi, dimana wisatawan akan mendapatkan penjelasan dari guide lokal mengenai perkebunan kopi dan wilayah/areal perkebunan dengan batas alam tertentu, seperti sungai dan jalan yang terdapat di Desa Munduk. Setelah melewati area perkebunan kopi, wisatawan dapat melihat kerajinan tangan (handycraft) yang dijual oleh masyarakat lokal. Perjalanan kemudian dilanjutkan menuju air terjun kedua, yaitu Air Terjun Munduk atau biasa dikenal dengan (Red Coral Waterfall). Setelah menikmati pemandangan dan bersantai di air terjun, wisatawan akan melanjutkan perjalanan menuju tempat cooking class. Pada saat cooking class, wisatawan akan ditemani dan diajarkan memasak oleh masyarakat lokal (pawongan atau hubungan manusia dengan sesama manusia) untuk makan siang bagi wisatawan tersebut. Setelah makan siang, wisatawan kemudian berkunjung dan dapat melihat Pura Kopi yang memiliki konsep arsitektur Bali dengan pembagian ruang yaitu jeroan (zone terdalam) dan jaba sisi (zone terluar) untuk dapat menampung masyarakat bersembahyang secara nyaman. Pura Kopi merupakan tempat suci yang khusus dibangun oleh kumpulan para petani perkebunan sebagai tempat untuk bersyukur kepada Tuhan atas hasil yang didapatkan dari perkebunan cengkeh dan kopi disetiap harinya. Pura Kopi tersebut merupakan akhir acara dari paket wisata Munduk Waterfall Tracking, dimana wisatawan selanjutnya akan meninggalkan Desa Munduk dan kembali ke hotel.

Harga paket Munduk Waterfall Tracking di Desa Munduk untuk peserta individu dan kolektif dapat dilihat pada Tabel 2, dengan peserta kolektif sebanyak 7 orang akan mendapatkan 1 komplimen dengan Agent Commission sejumlah $10 \%$ dan Surcharge $20 \%$ dari harga per peserta. Berdasarkan paket wisata ini, dapat disertakan perencanaan harga yang ditentukan pada Tabel 2 berikut. 
Tabel 2. Harga Paket Wisata Munduk Waterfall Tracking

\begin{tabular}{|c|c|c|c|c|c|}
\hline \multirow{3}{*}{ Uraian } & \multicolumn{5}{|c|}{ Jenis Kendaraan dan Jumlah Peserta } \\
\hline & \multicolumn{3}{|c|}{ Avanza } & \multirow{2}{*}{$\begin{array}{c}\text { APV } \\
4-6 \\
\end{array}$} & \multirow{2}{*}{$\begin{array}{l}\text { Elf } \\
7-9 \\
\end{array}$} \\
\hline & 1 & 2 & 3 & & \\
\hline $\begin{array}{l}\text { Jumlah Biaya } \\
\text { Tetap }\end{array}$ & Rp. 905.000 & Rp. 905.000 & Rp. 905.000 & Rp. 905.000 & Rp.1. 105.000 \\
\hline $\begin{array}{l}\text { Jumlah Biaya } \\
\text { Tidak Tetap }\end{array}$ & Rp. 190.000 & Rp. 190.000 & Rp. 190.000 & Rp. 190.000 & Rp. 190.000 \\
\hline $\begin{array}{l}\text { Jumlah Biaya } \\
\text { Per Peserta } \\
\end{array}$ & Rp. 1.095 .000 & Rp. 642.500 & Rp. 491.667 & Rp. 416.250 & Rp. 347.857 \\
\hline Surcharge & Rp. 219.000 & Rp. 128.500 & Rp. 98.333 & Rp. 83.250 & Rp. 69.571 \\
\hline Nett Price & Rp. 1.314 .000 & Rp. 771.000 & Rp. 590.000 & Rp. 499.500 & Rp. 417.428 \\
\hline $\begin{array}{l}\text { Price Include } \\
\text { FOC }\end{array}$ & 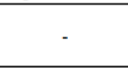 & & se & & Rp. 487.000 \\
\hline Selling Price & Rp. 1.460 .000 & Rp. 856.667 & Rp. 655.555 & Rp. 555.000 & Rp. 541.111 \\
\hline
\end{tabular}

Sumber: Hasil, 2016

\section{Paket Wisata Munduk Rice Field Tracking}

Keberangkatan menuju Pesanggrahan Desa Munduk dimulai dari hotel yang terletak di kawasan Lovina, Kecamatan Buleleng pada pukul 07.00 WITA. Setelah tiba di Pesanggrahan, wisatawan langsung menikmati sarapan pagi dengan menu yang berasal dari produk lokal, kemudian diarahkan menuju tempat meditasi. Kegiatan meditasi merupakan jalan untuk meraih ketenangan batin dan mendekatkan diri dengan Sang Pencipta (parahyangan atau hubungan manusia dengan Tuhan), kegiatan tersebut berlangsung selama 30 menit sebelum kegiatan tracking dimulai. Wisatawan yang sudah selesai bermeditasi diberikan waktu 10 menit untuk mempersiapkan perlengkapan, serta mendapat penjelasan singkat tentang komitmen untuk tidak membuang sampah di setiap objek yang dikunjungi dan tidak merusak tumbuhtumbuhan demi pelestarian lingkungan di Desa Munduk (palemahan atau hubungan manusia dengan alam). Perjalanan awal dimulai dari mengunjungi pasar tradisional di Desa Munduk, wisatawan dapat melihat dan mendapatkan penjelasan tentang Pura Melanting serta kegiatan pedagang-pedagang lokal (mesangkep). Selanjutnya wisatawan akan berkunjung ke perkebunan cengkeh untuk dapat melihat kegiatan masyarakat lokal memetik dan menjemur cengkeh untuk nantinya diproses ke tahap selanjutnya. Setelah melihat perkebunan cengkeh, wisatawan melanjutkan perjalanannya melewati area persawahan pertama, serta mendapatkan penjelasan tentang organisasi Subak Dayan (organisasi masyarakat lokal Desa Munduk yang khusus mengatur sistem pengairan sawah untuk bercocok tanam). Perjalanan kemudian dilanjutkan dengan melewati perkebunan kopi yang berada di kiri dan kanan jalan. Wisatawan kemudian akan menikmati pemandangan area persawahan dan laut utara Bali di rest area yang sudah disediakan, dimana rest area tersebut berada di tengah-tengah persawahan. Wilayah atau areal persawahan di Desa Munduk memiliki batas-batas alam tertentu, seperti sungai, jalan, dan pematang besar. Setelah 15 menit beristirahat dan bersantai di rest area, perjalanan kembali dilanjutkan menuju Pura Bedugul atau biasa disebut Pura Subak yang memiliki konsep arsitektur Bali dengan pembagian ruang yaitu jeroan (zone terdalam) dan jaba sisi (zone terluar) untuk dapat menampung masyarakat bersembahyang secara nyaman. Pura Bedugul merupakan tempat suci yang khusus dibangun oleh kumpulan para petani, diperuntukkan bagi Dewi Sri sebagai manifestasi Tuhan selaku dewi kesuburan. Setelah sampai di Pura Bedugul, tentunya banyak penjelasan yang akan didapatkan wisatawan dari local guide, baik dari sejarah hingga kegunaan Pura bagi masyarakat lokal terutama petani disetiap harinya. Akhir dari perjalanan wisata tracking ditutup dengan mengunjungi tempat makan yang dimiliki masyarakat lokal. Setelah sampai di tempat makan, wisatawan akan diajarkan membuat makanan yang sudah ditentukan dalam kegiatan cooking class (pawongan atau hubungan manusia dengan sesama manusia) dan menikmati coffee break sebelum kembali menuju ke hotel.

Harga paket Munduk Rice Field Tracking di Desa Munduk untuk peserta individu dan kolektif dapat dilihat pada Tabel 3, dengan peserta kolektif sebanyak 7 orang akan mendapatkan 1 komplimen dengan Agent Commission sejumlah $10 \%$ dan Surcharge $20 \%$ dari harga per peserta. Berdasarkan paket wisata ini, dapat disertakan perencanaan harga yang ditentukan pada Tabel 3 berikut. 
Tabel 3. Harga Paket Wisata Munduk Rice Field Tracking

\begin{tabular}{|c|c|c|c|c|c|}
\hline \multirow{3}{*}{ Uraian } & \multicolumn{5}{|c|}{ Jenis Kendaraan dan Jumlah Peserta } \\
\hline & \multicolumn{3}{|c|}{ Avanza } & \multirow{2}{*}{$\begin{array}{c}\text { APV } \\
4-6\end{array}$} & \multirow{2}{*}{$\begin{array}{l}\text { Elf } \\
7-9 \\
\end{array}$} \\
\hline & 1 & 2 & 3 & & \\
\hline $\begin{array}{l}\text { Jumlah Biaya } \\
\text { Tetap }\end{array}$ & Rp. 905.000 & Rp. 905.000 & Rp. 905.000 & Rp. 905.000 & Rp.1. 105.000 \\
\hline $\begin{array}{l}\text { Jumlah Biaya } \\
\text { Tidak Tetap }\end{array}$ & Rp. 170.000 & Rp. 170.000 & Rp. 170.000 & Rp. 170.000 & Rp. 170.000 \\
\hline $\begin{array}{l}\text { Jumlah Biaya } \\
\text { Per Peserta }\end{array}$ & Rp. 1.075 .000 & Rp. 622.500 & Rp. 471.666 & Rp. 396.250 & Rp. 327.857 \\
\hline Surcharge & Rp. 215.000 & Rp. 124.500 & Rp. 94.333 & Rp. 79.250 & Rp. 65.571 \\
\hline Nett Price & Rp. 1.290 .000 & Rp. 747.000 & Rp. 565.999 & Rp. 475.500 & Rp. 393.428 \\
\hline $\begin{array}{l}\text { Price Include } \\
\text { FOC }\end{array}$ & - & 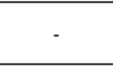 & - & - & Rp. 458.999 \\
\hline Selling Price & Rp. 1.433.333 & Rp. 830.000 & Rp. 628.887 & Rp. 528.333 & Rp. 509.998 \\
\hline
\end{tabular}

Sumber: Hasil, 2016

\section{SIMPULAN DAN SARAN Simpulan}

Berdasarkan hasil dan pembahasan tersebut dapat disimpulkan bahwa Desa Munduk memiliki berbagai macam potensi wisata yang dapat dikembangkan sebagai daya tarik wisata dari segi pemandangan alam, kesenian, kepercayaan masyarakat lokal, kebiasaan penduduk, dan bangunan-bangunan bersejarah. Paket wisata tracking di Desa Munduk terdiri dari Munduk Waterfall Tracking dan Munduk Rice Field Tracking yang dikemas dalam bentuk uraian dan grafik. Kedua paket wisata tracking di Desa Munduk diimplementasikan dengan konsep Tri Hita Karana yang terdiri atas parahyangan (hubungan manusia dengan Tuhan) yaitu adanya kegiatan meditasi, mengunjungi dan mendapatkan penjelasan tentang tempat suci (Pura), pawongan (hubungan manusia dengan manusia) yaitu adanya kesempatan bagi wisatawan untuk berinteraksi dengan masyarakat lokal, serta adanya penjelasan tentang kegiatan dan organisasi masyarakat lokal, sedangkan palemahan (hubungan manusia dengan alam) yaitu adanya penjelasan tentang batas-batas alam dan komitmen untuk menjaga kebersihan serta tidak merusak tumbuh-tumbuhan demi pelestarian lingkungan di Desa Munduk.

\section{Saran}

Berdasarkan kesimpulan diatas, adapun saran yang tentunya dapat berguna bagi pengembangan wisata tracking di Desa Munduk untuk kedepannya, yaitu masyarakat lokal sebaiknya mampu untuk menjaga kebersihan dengan tidak membuang sampah di sembarang tempat, dikarenakan hal tersebut merupakan salah satu ancaman terbesar yang dapat mengganggu perkembangan wisata tracking di Desa Munduk. Keamanan jalur tracking, dimana masih terdapat beberapa anak tangga yang rusak untuk menuju ke air terjun dan tentunya apabila dalam kondisi hujan akan dapat membahayakan wisatawan. Peran dari pemerintah daerah juga sangat dibutuhkan dalam pengembangan wisata tracking di Desa Munduk. Pemerintah daerah sebaiknya dapat memberikan bantuan dana untuk perbaikan jalur tracking serta sosialisasi tentang pentingnya menjaga kebersihan lingkungan kepada masyarakat lokal Desa Munduk, sehingga nantinya tumbuh kesadaran dari masyarakat lokal terhadap kebersihan lingkungan.

\section{DAFTAR PUSTAKA}

Anonim. 2014. Buku Panduan Tri Hita Karana Awards \& Accreditation. Denpasar: Yayasan Tri Hita Karana Bali

Sugiyono. 2012. Metode Penelitian Kuantitatif, Kualitatif, dan $R \& D$. Bandung: Alfabeta.

Suyitno, 2001. Perencanaan Wisata. Yogyakarta: Kanisius.

Utama, I Gusti Bagus Rai dan Ni Made Eka Mahadewi. 2012. Metodologi Penelitian Pariwisata \& Perhotelan. Yogyakarta: $\mathrm{CV}$. Andi Offset

Yoeti, Oka A. 2002. Perencanaan Strategis Pemasaran Daerah Tujuan Wisata. Jakarta: PT. Pradnya Paramita. 